\title{
Asupan lemak jenuh dan serat pada remaja obesitas kaitannya dengan sindrom metabolik
}

Dietary saturated fat and fiber intake in obese adolescents and its association to metabolic syndrome

\author{
Nurmasari Widyastuti $^{1 *}$, Fillah Fithra Dieny ${ }^{1}$, Deny Yudi Fitranti ${ }^{1}$
}

${ }^{1}$ Departemen Ilmu Gizi, Fakultas Kedokteran Universitas Diponegoro, Semarang

\begin{abstract}
Background: There is an emerging global increase of metabolic syndrome prevalence due to increasing of obesity. Obesity and metabolic syndrome beginning in childhood progressing into adulthood. Dietary saturated fat and fiber intake play a role in etiology in obesity. Objective: This study was to examine the associations between dietary saturated fat intake, fiber intake and components of metabolic syndrome among obese adolescents. Methods: A cross-sectional study was conducted to 57 obese students aged 13-15 years old of SMP Nasima and SMP Kesatrian 2 Semarang, based on body mass index for ages. Subjects of this study were collected consecutively. Data were collected through waist circumference and blood pressure measurements, fasting biochemical serum analysis and dietary intake assessment. Rank Spearman and Pearson correlation test was used to examine the associations between of dietary saturated fat and fiber intake to components of metabolic syndrome. Results: There were 46 subjects (80,7\%) had metabolic syndrome and 11 subjects $(19,3 \%)$ had pre-metabolic syndrome. There was no association between dietary saturated fat intake and waist circumference, HDL cholesterol, triglyceride, fasting blood glucose levels and blood pressure. Fiber intake was negatively associated with blood triglyceride levels $(r=-0.340 ; p=0.01)$. Conclusions: There was no association between dietary saturated fat intake and components of metabolic syndrome. There was an association between dietary fiber intake with blood triglyceride levels. Dietary fiber intake has an important role in lipid metabolism.
\end{abstract}

KEY WORDS: dietary saturated fat, dietary fiber, obesity, metabolic syndrome, adolescent

\begin{abstract}
ABSTRAK
Latar belakang: Obesitas menjadi masalah kesehatan yang penting dan semakin meningkat prevalensinya pada anak maupun remaja. Salah satu konsekuensi dari obesitas adalah meningkatnya risiko terhadap sindrom metabolik, yang prevalensinya cenderung meningkat seiring dengan meningkatnya kasus obesitas. Obesitas serta sindrom metabolik yang berkembang pada masa anak dan remaja dapat berlanjut sampai dewasa. Asupan makan khususnya asupan lemak jenuh dan serat merupakan faktor lingkungan yang berpengaruh kuat terhadap terjadinya obesitas pada remaja. Tujuan: Mengetahui asupan lemak jenuh dan serat pada remaja obesitas dan kaitannya dengan sindrom metabolik. Metode: Desain penelitian adalah cross-sectional dengan melibatkan murid kelas VII dan VIII di SMP Nasima dan SMP Kesatrian 2 Semarang, baik murid laki-laki maupun perempuan, berumur 13-15 tahun, berjumlah 57 remaja obesitas yang dipilih secara konsekutif. Pada subjek dilakukan pemeriksaan kadar kolesterol HDL, trigliserida, dan glukosa darah puasa; pengukuran tekanan darah; pengukuran antropometri; dan wawancara asupan makan. Analisis bivariat menggunakan uji korelasi Pearson atau Spearman untuk mengetahui hubungan asupan lemak jenuh dan serat dengan beberapa komponen sindrom metabolik. Hasil: Didapatkan 46 subjek (80,7\%) mengalami sindrom metabolik dan 11 subjek (19,3\%) mengalami pra sindrom metabolik. Asupan lemak jenuh tidak berhubungan dengan lingkar pinggang, kadar kolesterol HDL, trigliserida, glukosa darah puasa maupun tekanan darah. Asupan serat berhubungan negatif dengan kadar trigliserida darah $(\mathrm{r}=-0,340 ; \mathrm{p}=0,01)$. Simpulan: Asupan lemak jenuh tidak berhubungan dengan lingkar pinggang, kadar kolesterol HDL, trigliserida, glukosa darah puasa maupun tekanan darah. Ada hubungan antara asupan serat dengan kadar trigliserida darah. Asupan serat memberikan kontribusi penting terhadap metabolisme lemak
\end{abstract}

KATA KUNCI: asupan lemak jenuh, asupan serat, obesitas, sindrom metabolik, remaja

\footnotetext{
* Korespondensi: Nurmasari Widyastuti, Departemen Ilmu Gizi, Fakultas Kedokteran Universitas Diponegoro Semarang, Jl. Dr.Sutomo No.18 Semarang, Jawa Tengah, Indonesia, e-mail: widyastutianlene@gmail.com
} 


\section{PENDAHULUAN}

Obesitas menjadi masalah kesehatan yang penting di seluruh dunia baik di negara-negara maju maupun negara berkembang dan semakin meningkat prevalensinya pada anak maupun remaja $(1,2)$. Di Indonesia, data Riset Kesehatan Dasar (Riskesdas) 2013 menunjukkan bahwa 2,5\% remaja usia 13-15 tahun mengalami obesitas, sementara di Jawa Tengah, prevalensi obesitas pada remaja usia di atas 13-15 tahun sebesar 2,4\% (3). Salah satu konsekuensi dari obesitas adalah meningkatnya risiko terhadap sindrom metabolik, yang prevalensinya cenderung meningkat seiring dengan meningkatnya kasus obesitas $(4,5)$. Obesitas serta sindrom metabolik yang berkembang pada masa anak dan remaja dapat berlanjut sampai dewasa $(2,5)$.

Sindrom metabolik merupakan keadaan klinis pada seseorang yaitu terdapat sekumpulan kelainan metabolik antara lain obesitas, kelainan kadar lemak darah terutama kolesterol high density lipoprotein (HDL) dan trigliserida, serta peningkatan tekanan darah dan kadar glukosa darah puasa, yang dapat meningkatkan risiko terhadap berkembangnya penyakit kardiovaskuler (6-9). Laporan dari National Cholesterol Education Program Adult Treatment Panel III (NCEP-ATP III) menunjukkan peningkatan prevalensi sindrom metabolik remaja dari periode 1988-1994 ke periode 1999-2000 yaitu 4,2\% menjadi 6,4\% (5).

Penyebab obesitas sebagai salah satu komponen sindrom metabolik sangatlah kompleks dan multifaktor. Terjadinya obesitas melibatkan interaksi yang kompleks antara faktor genetik dan faktor lingkungan, seperti kurang aktivitas fisik, asupan makan, dan aspek-aspek sosial (10). Asupan makan merupakan faktor lingkungan yang berpengaruh kuat terhadap terjadinya obesitas pada remaja. Berdasarkan studi yang dilakukan di Amerika pada tahun 2002 menunjukkan lebih dari 90\% remaja selalu mengkonsumsi kudapan di antara waktu makan yang sebagian besar kandungannya adalah lemak (11). Lemak memberikan kelezatan khusus dan tekstur yang disukai pada makanan. Hal ini dapat mendorong sebagian besar remaja mengkonsumsi makanan yang mengandung banyak lemak karena rasanya yang lezat. Makanan tinggi lemak yang dikonsumsi dalam jumlah berlebihan memberikan kontribusi terhadap asupan energi berlebihan dan jika tidak diimbangi dengan pengeluaran energi yang memadai dapat menyebabkan meningkatnya penyimpanan energi dalam sel lemak. Kondisi ini dapat mengakibatkan meningkatnya jumlah dan ukuran sel lemak sehingga terjadilah obesitas (5).

Penelitian di Yogyakarta dan di Kabupaten Bantul menunjukkan bahwa asupan lemak memberikan kontribusi penting terhadap terjadinya obesitas pada remaja SMP (12). Pada penelitian yang dilakukan di Malaysia tahun 2006, rerata asupan lemak berbeda secara signifikan di kalangan remaja yaitu kelompok obesitas memiliki rerata asupan lemak lebih tinggi dibandingkan dengan yang gizi kurang maupun normal. Pada kelompok obesitas, rerata asupan energi dari lemak lebih dari $30 \%$ dan rerata asupan energi dari karbohidrat kurang dari 55\% dari kebutuhan (13). Sementara itu, penelitian yang dilakukan di Malang pada remaja usia 13-19 tahun menunjukkan hasil yang serupa baik pada remaja obesitas dengan sindrom metabolik maupun non sindrom metabolik, rerata asupan lemak melebihi anjuran konsumsi lemak sehari, yaitu melebihi $30 \%$ dari total energi sehari dan rerata asupan energi dari karbohidrat kurang dari 55\% dari kebutuhan. Meskipun demikian, pada penelitian tersebut dijumpai bahwa rerata asupan lemak pada remaja dengan sindrom metabolik lebih tinggi daripada remaja non sindrom metabolik $(5,14)$. Penelitian yang dilakukan di Algeria pada bulan Desember 2011 hingga Juni 2012 menunjukkan bahwa rerata asupan lemak jenuh baik pada remaja obesitas laki-laki maupun perempuan melebihi $10 \%$ dari total energi sehari dan konsumsi asupan lemak jenuh melebihi 10\% dari total energi sehari berhubungan dengan obesitas abdominal pada remaja perempuan dan indeks massa tubuh (IMT) baik pada remaja laki-laki maupun perempuan (15). Asupan lemak jenuh yang tinggi berkontribusi terhadap peningkatan kadar kolesterol total melalui peningkatan kadar kolesterol low density lipoprotein (LDL) dan penurunan kadar kolesterol HDL (5). Rendahnya asupan serat pada remaja juga merupakan salah satu faktor yang berkontribusi terhadap obesitas (16). Angka kecukupan gizi (AKG) serat yang dianjurkan bagi orang Indonesia untuk usia 13-15 tahun adalah $30 \mathrm{~g}$ bagi remaja perempuan dan $35 \mathrm{~g}$ bagi remaja laki-laki (16). Penelitian di Amerika pada tahun 2003-2006 menunjukkan bahwa 
konsumsi serat yang rendah berhubungan dengan risiko terjadinya obesitas dan diabetes mellitus (DM) (17).

Berdasarkan pertimbangan bahwa asupan makan berkontribusi penting terhadap terjadinya obesitas yang merupakan faktor risiko sindrom metabolik, maka penelitian ini bertujuan untuk menjelaskan hubungan asupan lemak jenuh dan asupan serat terhadap sindrom metabolik pada remaja obesitas.

\section{BAHAN DAN METODE}

Penelitian ini dilakukan pada bulan Juni sampai dengan Agustus 2015 dengan melibatkan murid kelas VII dan VIII di SMP Nasima dan SMP Kesatrian 2 Semarang, baik murid laki-laki maupun perempuan. Jenis penelitian ini adalah observasional dengan rancangan crosssectional. Pemilihan subjek dilakukan dengan metode consecutive sampling, dengan kriteria inklusi usia 13-15 tahun; mempunyai status gizi obesitas (Z-score IMT/U $>2$ SD) menurut World Health Organization (WHO) 2005; tidak sedang menjalani diet karena penyakit tertentu seperti hipertensi, DM; bersedia mengikuti penelitian dengan mengisi formulir informed consent. Subjek yang absen atau sakit selama dilakukan penelitian dan mengundurkan diri sebelum penelitian selesai tidak diikutkan dalam penelitian ini. Pada consecutive sampling, semua subjek yang datang dan memenuhi kriteria pemilihan dimasukkan dalam penelitian sampai jumlah subjek yang diperlukan terpenuhi. Consecutive sampling merupakan jenis non-probability sampling yang paling baik dan tidak memerlukan randomisasi atau sistem pengacakan pada pemilihan sampel dalam kelompok yang akan diteliti (18).

Penelitian ini dilengkapi dengan ethical clearance yang ditandatangani oleh Komisi Etik Fakultas Kedokteran Universitas Diponegoro/Rumah Sakit Umum Pusat Dr. Kariadi Semarang. Besar sampel dihitung menggunakan rumus dengan proporsi sindrom metabolik pada remaja obesitas $(\mathrm{P})$ berdasarkan penelitian sebelumnya sebesar $30 \%(0,3)$; nilai $\mathrm{Z} \alpha=1,96(\alpha=0,05$ satu arah); $\mathrm{Q}=(1$ $\mathrm{P}=0,7)$; nilai presisi (d) sebesar $10 \%$; dan jumlah populasi (N) sebesar 100 orang sehingga ditetapkan jumlah sampel sebanyak 45 orang. Besar sampel kemudian dikoreksi untuk menghindari sampel yang drop out dengan menambahkan sejumlah sampel agar sampel tetap terpenuhi dengan rumus $n=n /(1-f)$ sehingga ditetapkan jumlah sampel sebanyak 50 orang (19).

Variabel bebas terdiri dari asupan lemak jenuh dan asupan serat sedangkan variabel terikat terdiri dari lingkar pinggang, kadar kolesterol HDL, trigliserida, glukosa darah puasa, tekanan darah sistolik, dan tekanan darah diastolik. Pada subjek dilakukan pemeriksaan kadar kolesterol HDL, trigliserida, dan glukosa darah puasa; pengukuran tekanan darah; pengukuran antropometri; dan wawancara asupan makan. Pengambilan sampel darah dilakukan pada pagi hari, setelah subjek berpuasa minimal 8 jam. Pengambilan darah puasa dilakukan oleh petugas laboratorium terakreditasi. Data antropometri yang dikumpulkan adalah berat badan, tinggi badan, dan ukuran lingkar pinggang. Pengukuran berat badan diukur menggunakan timbangan berat badan dengan ketelitian $0,1 \mathrm{~kg}$. Tinggi badan diukur menggunakan mikrotoise dengan ketelitian $0,1 \mathrm{~cm}$ dan lingkar pinggang diukur menggunakan pita ukur. Pengukuran tekanan darah dilakukan oleh tenaga ahli menggunakan sphygmomanometer air raksa. Tekanan darah diukur menggunakan metode tidak langsung dengan cara auskultasi.

Penentuan sindrom metabolik ditentukan berdasarkan kriteria dari National Cholesterol Education Program Adult Treatment Panel III (NCEP ATP III) yang sudah disesuaikan untuk remaja. Seseorang dikatakan mengalami sindrom metabolik bila memiliki sedikitnya 3 (tiga) komponen dari 5 (lima) komponen sebagai berikut yaitu mengalami obesitas abdominal (lingkar pinggang $\geq$ persentil ke-90); kadar trigliserida $\geq 110 \mathrm{mg} / \mathrm{dl}$; kadar kolesterol HDL $\leq 40 \mathrm{mg} / \mathrm{dl}$; kadar glukosa darah puasa $\geq 110 \mathrm{mg} / \mathrm{dl}$; dan tekanan darah subjek dikatakan tinggi apabila salah satu atau keduanya $\geq$ persentil ke 90 . Persentil ke 90 untuk lingkar pinggang pada remaja yaitu lingkar pinggang untuk laki laki $93 \mathrm{~cm}$ dan perempuan 87 cm $(2,20)$. Sementara itu, persentil ke 90 untuk tekanan darah pada remaja yaitu tekanan darah sistolik $125 \mathrm{mmHg}$ dan tekanan darah diastolik $70 \mathrm{mmHg}$ (21). Kriteria subjek termasuk pra sindrom metabolik jika memenuhi 1-2 komponen sindrom metabolik. Pra sindrom metabolik merupakan bentuk sindrom metabolik dengan derajat keparahan yang ringan. 
Asupan lemak jenuh dan serat merupakan ratarata asupan lemak jenuh dan serat dari makanan yang diperoleh dari wawancara asupan makan menggunakan semiquantitative food frequency questionare (SFFQ) yang kemudian dikonversikan ke dalam satuan $\mathrm{g} /$ hari. Asupan lemak jenuh dikatakan tinggi apabila $>7 \%$ dari total kebutuhan energi sehari (22). Asupan serat pada remaja perempuan usia 13-15 tahun dikatakan rendah jika $<30$ g sehari dan $<35$ g bagi remaja laki-laki (16). Analisis univariat digunakan untuk mendeskripsikan karakteristik subjek penelitian. Uji Kolmogorov-Smirnov digunakan untuk menguji normalitas data. Analisis bivariat menggunakan uji korelasi Pearson atau rank Spearman untuk menguji hubungan asupan lemak jenuh dan serat dengan beberapa komponen sindrom metabolik.

\section{HASIL}

Berdasarkan hasil skrining pada 288 murid di SMP Nasima Semarang dan 50 murid di SMP Kesatrian 2 Semarang, didapatkan 67 remaja $(19,8 \%)$ dengan status gizi obesitas, tetapi hanya 57 remaja obesitas yang memenuhi kriteria inklusi. Sebagian besar subjek adalah perempuan (59,6\%; $n=34$ orang). Sebanyak 43 subjek $(75,4 \%)$ termasuk dalam kategori obesitas abdominal; 42 subjek $(73,7 \%)$ mempunyai kadar trigliserida yang tinggi ( $\geq 110 \mathrm{mg} / \mathrm{dl}) ; 35$ subjek $(61,4 \%)$ mempunyai kadar kolesterol HDL rendah; 7 subjek (12,3\%) mempunyai kadar glukosa darah puasa tinggi; dan 53 subjek (93\%) mempunyai tekanan darah tinggi. Terdapat 46 subjek $(80,7 \%)$ mengalami sindrom metabolik dan 11 subjek (19,3\%) mengalami pra sindrom metabolik. Sindrom metabolik lebih banyak dijumpai pada subjek laki-laki daripada subjek perempuan (Tabel 1).

Hasil penelitian ini menunjukkan prevalensi sindrom metabolik sebesar $82,6 \%$ pada subjek laki-laki dan $79,4 \%$ pada subjek perempuan. Pada penelitian ini juga dijumpai bahwa 3 subjek (5,3\%) dengan 1 (satu) komponen sindrom metabolik; 8 subjek (14,0\%) dengan
Tabel 1. Karakteristik umum subjek penelitian

\begin{tabular}{|c|c|c|c|c|c|c|}
\hline \multirow[t]{2}{*}{ Karakteristik } & \multirow[t]{2}{*}{$\mathbf{F}$} & \multirow[t]{2}{*}{$\%$} & \multicolumn{2}{|c|}{$\begin{array}{c}\text { Sindrom } \\
\text { metabolik }\end{array}$} & \multicolumn{2}{|c|}{$\begin{array}{c}\text { Pra } \\
\text { sindrom } \\
\text { metabolik }\end{array}$} \\
\hline & & & $\mathbf{n}$ & $\%$ & $\mathbf{n}$ & $\%$ \\
\hline \multicolumn{7}{|l|}{ Jenis kelamin } \\
\hline Laki-laki & 23 & 40,4 & 19 & 82,6 & 4 & 58,7 \\
\hline Perempuan & 34 & 59,6 & 27 & 79,4 & 7 & 20,5 \\
\hline \multicolumn{7}{|l|}{ Lingkar pinggang $(\mathrm{cm})$} \\
\hline Obesitas abdominal & 43 & 75,4 & 39 & 90,7 & 4 & 9,3 \\
\hline Tidak obesitas & 14 & 24,6 & 7 & 50,0 & 7 & 50,0 \\
\hline \multicolumn{7}{|l|}{ Trigliserida (mg/dl) } \\
\hline Tinggi & 42 & 73,7 & 39 & 92,9 & 3 & 7,1 \\
\hline Normal & 15 & 26,3 & 7 & 46,7 & 8 & 53,3 \\
\hline \multicolumn{7}{|l|}{ HDL (mg/dl) } \\
\hline Rendah & 35 & 61,4 & 33 & 94,3 & 2 & 5,7 \\
\hline Normal & 22 & 38,6 & 13 & 59,1 & 9 & 40,9 \\
\hline \multicolumn{7}{|c|}{ Glukosa darah puasa (mg/dl) } \\
\hline Tinggi & 7 & 12,3 & 7 & 100,0 & 0 & 0 \\
\hline Normal & 50 & 87,7 & 39 & 78,0 & 11 & 22,0 \\
\hline \multicolumn{7}{|l|}{ Tekanan darah (mmHg) } \\
\hline Tinggi & 53 & 93,0 & 43 & 81,1 & 10 & 70,5 \\
\hline Normal & 4 & 7,0 & 3 & 75,0 & 4 & 25,0 \\
\hline
\end{tabular}

2 (dua) komponen sindrom metabolik; 24 subjek (42,1\%) dengan 3 (tiga) komponen sindrom metabolik; 21 subjek (36,8\%) dengan 4 komponen sindrom metabolik; dan 1 subjek (1,8\%) dengan 5 komponen sindrom metabolik.

Pada penelitian ini diketahui bahwa semua subjek mempunyai asupan lemak jenuh yang tinggi dengan rerata $17,89 \pm 3,83 \%$ dari total energi sehari dan asupan

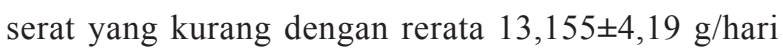
(Tabel 2).

Tabel 3 menunjukkan bahwa asupan lemak jenuh secara statistik tidak berhubungan dengan lingkar pinggang, kadar trigliserida, kolesterol HDL, glukosa darah puasa maupun tekanan darah. Sementara itu, asupan serat $(r=-0,340 ; p=0,01)$ berhubungan dengan kadar trigliserida namun tidak berhubungan dengan dengan lingkar pinggang, kolesterol HDL, glukosa darah puasa maupun tekanan darah. Korelasi asupan serat dengan kadar trigliserida bersifat negatif, artinya semakin tinggi

Tabel 2. Deskripsi asupan lemak jenuh dan serat

\begin{tabular}{lccrc}
\hline Asupan & Minimum & Maksimum & Rerata & SD \\
\hline Lemak jenuh (\% total energi) & 10 & 28 & 17,89 & 3,83 \\
Serat (g/hari) & 5,1 & 22,9 & 13,155 & 4,19 \\
\hline
\end{tabular}


Tabel 3. Analisis bivariat variabel asupan lemak jenuh dan serat dengan komponen sindrom metabolik

\begin{tabular}{lcccccccccccc}
\hline \multirow{2}{*}{ Variabel } & \multicolumn{2}{c}{ LP } & \multicolumn{2}{c}{ HDL } & \multicolumn{1}{c}{ TG } & \multicolumn{3}{c}{ GDP } & \multicolumn{2}{c}{ TD Sistolik } & TD Diastolik \\
\cline { 2 - 12 } & $\mathbf{r}$ & $\mathbf{p}$ & $\mathbf{r}$ & $\mathbf{p}$ & $\mathbf{r}$ & $\mathbf{p}$ & $\mathbf{r}$ & $\mathbf{p}$ & $\mathbf{r}$ & $\mathbf{p}$ & $\mathbf{r}$ & $\mathbf{p}$ \\
\hline $\begin{array}{l}\text { Lemak jenuh } \\
\text { \% dari total energi) }\end{array}$ & $-0,54$ & $0,69^{* *}$ & 0,04 & $0,76^{* *}$ & 0,01 & $0,37^{*}$ & 0,20 & $0,13^{* *}$ & $-0,01$ & $0,94^{*}$ & $-0,17$ & $0,18^{*}$ \\
Serat (g) & 0,01 & $0,92^{* *}$ & $-0,08$ & $0,52^{* *}$ & $-0,34$ & $\mathbf{0 , 0 1 *}$ & 0,03 & $0,78^{* *}$ & $-0,081$ & $0,52^{*}$ & 0,12 & $0,37^{*}$ \\
\hline
\end{tabular}

$\mathrm{LP}=$ lingkar pinggang; $\mathrm{HDL}=$ high density lipoprotein $; \mathrm{TG}=$ trigliserida; $\mathrm{GDP}=$ glukosa darah puasa; $\mathrm{TD}=$ tekanan darah; *Uji korelasi rank Spearman; ** Uji korelasi Pearson

asupan serat, maka kadar trigliserida darah semakin rendah.

\section{BAHASAN}

Prevalensi obesitas pada remaja dengan rentang usia 13-15 tahun dalam penelitian ini adalah 19,8\%. Prevalensi ini lebih tinggi jika dibandingkan dengan prevalensi obesitas pada remaja berusia 13-15 tahun di Jawa Tengah berdasarkan hasil Riskesdas tahun 2013 yaitu sebesar 2,4\% (3). Hal ini menunjukkan bahwa prevalensi obesitas pada remaja semakin meningkat. Pada penelitian ini juga ditemukan bahwa $80,7 \%$ remaja obesitas mengalami sindrom metabolik. Prevalesi ini lebih tinggi jika dibandingkan dengan prevalensi sindrom metabolik pada remaja obesitas di salah satu SMP swasta di Semarang pada tahun 2009 yaitu sebesar 31,6\% (2). Hal ini menunjukkan bahwa prevalensi sindrom metabolik semakin meningkat dengan berkembangnya obesitas.

Pada penelitian ini ditemukan sindrom metabolik lebih banyak dijumpai pada remaja laki-laki $(82,6 \%)$ dibandingkan remaja perempuan $(79,4 \%)$. Hasil penelitian ini tidak berbeda dengan hasil survei yang dilakukan National Health and Nutrition Examination Survey (NHANES) pada remaja tahun 2001-2006, yaitu prevalensi sindrom metabolik lebih tinggi pada remaja laki-laki $(10,8 \%)$ dibandingkan remaja perempuan $(6,1 \%)$ (23). Hal ini dapat terjadi karena pada remaja laki-laki, terutama yang mengalami obesitas, cenderung mempunyai deposit lemak di daerah atas tubuh khususnya pada tengkuk, leher, bahu, dan perut yang disebut obesitas android. Pada obesitas tipe android (obesitas sentral), lemak berakumulasi sebagai lemak viseral/intraabdominal. Obesitas tipe android berisiko mengalami sindrom metabolik dan penyakit kardiovaskular, khususnya jika terdapat lemak intra-abdominal yang berlebihan. Lemak intra-abdomimal lebih sensitif terhadap stimulus lipolisis dan memiliki kemampuan lebih besar dalam menghasilkan asam lemak bebas. Kelebihan asam lemak bebas intraselular dan metabolik dapat memicu terjadinya resistensi insulin (24).

Remaja obesitas pada penelitian ini memiliki asupan lemak jenuh melebihi 7\% dari total energi sehari. Sementara kebutuhan remaja akan lemak jenuh adalah kurang dari 7\% total energi sehari. Remaja dengan asupan lemak jenuh yang tinggi lebih berisiko mengalami obesitas dibandingkan remaja dengan asupan lemak jenuh yang cukup dan rendah (16). Asupan lemak jenuh yang tinggi akan memberikan peluang untuk meningkatkan kadar kolesterol total melalui peningkatan kadar kolesterol LDL dan penurunan kadar kolesterol HDL, meskipun pada penelitian ini secara statistik menunjukkan tidak ada hubungan yang bermakna antara asupan lemak jenuh dengan semua komponen sindrom metabolik.

Pada penelitian ini juga diketahui bahwa asupan serat pada remaja obesitas belum memenuhi angka kecukupan gizi (AKG) serat yang dianjurkan untuk remaja usia 13-15 tahun, asupan serat yang dianjurkan adalah $30 \mathrm{~g}$ bagi remaja perempuan dan $35 \mathrm{~g}$ bagi remaja laki-laki (16). Hasil analisis bivariat menunjukkan bahwa secara statistik asupan serat berhubungan dengan kadar trigliserida darah namun tidak berhubungan dengan lingkar pinggang, kolesterol HDL, glukosa darah puasa maupun tekanan darah. Korelasi asupan serat dengan kadar trigliserida bersifat negatif, artinya semakin tinggi asupan serat, maka kadar trigliserida darah semakin rendah. Banyaknya subjek yang menderita hipertrigliseridemia dalam penelitian ini dapat dikaitkan dengan rendahnya asupan serat makanan yang dimiliki oleh subjek. Trigliserida merupakan lipida utama dalam makanan. Kadar trigliserida darah dipengaruhi oleh 
asupan tinggi gula dan lemak. Serat makanan berperan dalam mengendalikan kadar lemak darah termasuk kadar trigliserida darah dengan cara memperlambat absorpsi gula dan mengikat asam empedu, lemak, dan kolesterol serta mengeluarkannya bersama feses (25-26). Hasil penelitian ini tidak jauh berbeda dengan hasil penelitian di Amerika pada tahun 2011 yang menunjukkan bahwa asupan serat berhubungan dengan sindrom metabolik, asupan serat yang tinggi mengurangi risiko terhadap terjadinya sindrom metabolik sementara asupan lemak jenuh tidak berhubungan dengan risiko terhadap sindrom metabolik (27).

Keterbatasan penelitian ini adalah tidak mengendalikan aktivitas fisik subjek yang kemungkinan juga memberikan kontribusi terhadap hasil penelitian ini. Selain itu, jumlah subjek yang digunakan relatif kecil dengan pemilihan subjek yang dilakukan secara non random. Oleh karena itu, hasil penelitian ini tidak dapat digeneralisasi untuk setiap remaja obesitas.

\section{SIMPULAN DAN SARAN}

Asupan lemak jenuh tidak berhubungan dengan lingkar pinggang, kadar kolesterol HDL, trigliserida, glukosa darah puasa maupun tekanan darah. Ada hubungan antara asupan serat dengan kadar trigliserida darah. Asupan serat yang cukup memberikan kontribusi penting terhadap pengendalian kadar trigliserida darah pada remaja obesitas. Subjek penelitian disarankan untuk memperbaiki pola makan, dengan mengurangi konsumsi bahan makanan yang mengandung banyak lemak jenuh dan meningkatkan asupan serat makanan.

\section{UCAPAN TERIMA KASIH}

Ucapan terima kasih penulis sampaikan kepada Fakultas Kedokteran Universitas Diponegoro yang telah mendanai penelitian ini.

\section{Pernyataan konflik kepentingan}

Penulis menyatakan tidak ada konflik kepentingan dengan pihak-pihak yang terkait dalam penelitian ini

\section{RUJUKAN}

1. Umboh A, Jully K, Johannes E. Hubungan antara resistensi insulin dan tekanan darah pada anak obese. Sari Pediatri 2007;8(4):289-93.

2. Mexitalia M, Utari A, Sakundarno M, Yamauchi T, Hertanto WS, Agustinus S. Sindrom metabolik pada Remaja Obesitas. M Med Indonesia 2009;43(6):300-6.

3. Badan Penelitian dan Pengembangan Kesehatan Kementerian Kesehatan RI. Riset Kesehatan Dasar 2013. [series online] 2013 [cited 21 Nov 2015]. Available from: URL: http://www.depkes.go.id.

4. Raj M, Kumar RK. Obesity in children \& adolescents. Indian J Med Res 2010;132(5):598-607.

5. Sargowo D, Sri Andarini.The relationship between food intake and adolescent metabolic syndrome. J Kardiol Indones 2011;32:14-23.

6. Djokomoeljanto. Metabolic syndrome and nutrition. Proceeding Seminar dan Pra Konggres PDGMI; 2009; Semarang.

7. Miranda PJ, DeFronzo RA, Califf RM, Guyton JR. Metabolic syndrome: definition, pathophysiology, and mechanisms. Am Heart J 2005;149(1):33-45.

8. Fan AZ. Etiology of the metabolic syndrome. Curr Cardiol Rev 2007;3:232-9.

9. Grundy SM. Obesity, metabolic syndrome, and cardiovascular disease. J Clin Endocrinol Metab 2004;89(6):2595-600.

10. Whitney EN, Rolfes SR. Understanding nutrition. USA: Thomson Wadsworth; 2002.

11. Abudayya AH, et al. Sociodemoghrapic correlation of food habits among school adolescent (12-15 year) in North Gaza Strip. Norway: University of Oslo; 2009.

12. Medawati A, Hamam H, IDP Pramantara. Hubungan antara asupan energi, asupan lemak, dan obesitas pada remaja sltp di kota yogyakarta dan di kabupaten bantul. Jurnal Gizi Klinik Indonesia 2005;1(3):119-29

13. S, Zalilah M, Khor GL, Mirnalini K, Norimah AK, Ang M. Dietary intake, physical activity and energy expenditure of Malaysian adolescents. Singapore Medical Journal 2006;47(6):491-8.

14. Suryaputra, Kartika, Siti RN. perbedaan pola makan dan aktivitas fisik antara remaja obesitas dengan non obesitas. Makara Kesehatan 2012;16(1):45-50.

15. Allioua M, Rabah D, Moustafa YM, Semir BSG, Harek D, Slimane B. Dietary fat intake, micronutritient and obesity among adolescent in Tlemcen (Western Algeria). Food and Nutrition Sciences 2015;6:860-8.

16. Hardinsyah, Hadi R, Victor N. Kecukupan energi, protein, lemak dan karbohidrat. [series online] 2013 [cited $21 \mathrm{Nov}$ 
2015]. Available from: URL: https://hadiriyadiipb.files. wordpress.com.

17. Brauchla M, Juan W, Story J, Kranz S. Sources of dietary fiber and the association of fiber intake with childhood obesity risk (in 2-18 year olds) and diabetes risk of adolescents 12-18 year olds: NHANES 2003-2006. J Nutr Metab 2012;2012:736258.

18. Sastroasmoro S. Dasar-dasar metodologi penelitian klinis Edisi 5. Jakarta: Sagung Seto; 2014.

19. Lemeshow S, dkk. Besar sampel dalam penelitian kesehatan. Yogyakarta: Gadjah Mada University Press; 2002 .

20. Silveira LS, Buonani C, Monteiro PA, Mello Antunes BM, Freitas Júnior IF. Metabolic Syndrome: Criteria for Diagnosing in Children and Adolescents. Endocrinol Metab Synd 2013;2:118. doi: 10.4172/2161-1017.1000118

21. Tang L, Kubota M, Nagai A, Mamemoto K, Tokuda M. Hyperuricemia in obese children and adolescents : the relationship with metabolic syndrome. Pediatr Rep 2010;2(1):e12.
22. Gidding SS, Dennison BA, Birch LL, Daniels SR, Gillman MW, Van Horn L. Dietary recommendations for children and adolescents: a guide for practitioners: consensus statement from the American Heart Association. Circulation 2005;112(13):2061-75.

23. Johnson WD, Kroon JJ, Greenway FL, Bouchard C, Ryan D, Katzmarzyk PT. Prevalence of risk factors for metabolic syndrome in adolescents National Health and Nutrition Examination Survey (NHNES), 2001-2006. Arch Pediatr Adolesc Med 2009;163(4):371-7.

24. Haris S,Tambunan T. Hipertensi pada sindrom metabolik. Sari Pediatr 2009;11(4):257-63.

25. Almatsier S. Prinsip dasar ilmu gizi. Jakarta: PT Gramedia Pustaka Utama; 2009

26. Sizer FS, Whitney E. Nutrition concepts and controversies. USA: Thomson Wadsworth; 2006.

27. Carlson JJ, Joey CE, Gregory JN, Karen AO, Paul CY. Dietary fiber and nutrient density are inversely associated with the metabolic syndrome in US adolescents. J Am Diet Assoc 2011;111:1688-95. 